3. Salvadori PS, Costa DMC, Romano RFT, et al. What is the real role of the equilibrium phase in abdominal computed tomography? Radiol Bras. $2013 ; 46: 65-70$

4. Costa DMC, Salvadori PS, Monjardim RF, et al. When the noncontrastenhanced phase is unnecessary in abdominal computed tomography scans? A retrospective analysis of 244 cases. Radiol Bras. 2013;46:197202.

5. Teixeira ACV, Torres US, Westin CEG, et al. Multidetector-row computed tomography in the preoperative diagnosis of intestinal complications caused by clinically unsuspected ingested dietary foreign bodies: a case series emphasizing the use of volume rendering techniques. Radiol Bras. 2013;46:346-50.

6. Kierszenbaum ML, von Atzingen AC, Tiferes DA, et al. Colonografia por tomografia computadorizada na visão do médico encaminhador: qual o seu valor segundo a visão de especialistas? Radiol Bras. 2014;47:13540 .

7. Francisco FAF, Araújo ALE, Oliveira Neto JA, et al. Contraste hepatobiliar: diagnóstico diferencial das lesões hepáticas focais, armadilhas e outras indicações. Radiol Bras. 2014;47:301-9.

8. Terceiro MG, Faria IM, Alfenas R, et al. Hérnia de Amyand com apendicite perfurada. Radiol Bras. 2014;47(6):xi-xiii.

9. Cunha EFC, Rocha MS, Pereira FP, et al. Necrose pancreática delimitada e outros conceitos atuais na avaliação radiológica da pancreatite aguda. Radiol Bras. 2014;47:165-75.

10. Kadow JS, Fingerhut CJP, Fernandes VB, et al. Peritonite encapsulante: tomografia computadorizada e correlação cirúrgica. Radiol Bras. 2014; 47:262-4.

11. Pedrassa BC, Rocha EL, Kierszenbaum ML, et al. Tumores hepáticos incomuns: ensaio iconográfico - Parte 1. Radiol Bras. 2014;47:3106.

12. Pedrassa BC, Rocha EL, Kierszenbaum ML, et al. Tumores hepáticos incomuns: ensaio iconográfico - Parte 2. Radiol Bras. 2014;47:3749.

13. Shinakai-Yasuda MA, Telles Filho FQ, Mendes RP, et al. Consenso em paracoccidioidomicose. Rev Soc Bras Med Trop. 2006;39:297-310.

14. Campos EP, Padovani CR, Cataneo AMJ. Paracoccidioidomicose: estudo radiológico e pulmonar de 58 casos. Rev Inst Med Trop São Paulo. 1991; $33: 267-76$.

15. Costa MAB, Carvalho TN, Araújo Júnior CR, et al. Manifestações extrapulmonares da paracoccidioidomicose. Radiol Bras. 2005;38:45-52.

16. Tucker ON, Healy V, Jeffers M, et al. Granulomatous appendicitis. Surgeon. 2003; 1:286-9.

17. AbdullGaffar B. Granulomatous diseases and granulomas of the appendix. Int J Surg Pathol. 2010;18:14-20.

18. Bronner MP. Granulomatous appendicitis and the appendix in idiopathic inflammatory bowel disease. Semin Diagn Pathol. 2004;21:98-107.

19. Carr NJ. The pathology of acute appendicitis. Ann Diagn Pathol. 2000; $4: 46-58$.

20. Chojniak R, Vieira RAC, Lopes A, et al. Intestinal paracoccidioidomycosis simulating colon cancer. Rev Soc Bras Med Trop. 2000;33:309-12.

21. Birnbaum BA, Wilson SR. Appendicitis at the millennium. Radiology. 2000;215:337-48.

Priscila Gava ${ }^{1}$, Alessandro Severo Alves de Melo ${ }^{1}$, Edson Marchiori $^{1}$, Márcia Henriques de Magalhães Costa $^{1}$, Eric Pereira $^{1}$, Raissa Dantas Batista Rangel ${ }^{1}$

1. Hospital Universitário Antônio Pedro (HUAP), Rio de Janeiro, RJ, Brazil. Mailing Address: Dra. Priscila Gava. Rua Vítor Meireles, 198 Condomínio Green Country, Mata Paca. Niterói, RJ, Brazil, 24322 110. E-mail: pris_gava@hotmail.com.

http://dx.doi.org/10.1590/0100-3984.2014.0035

\section{Biliary colon: an unusual case of intestinal obstruction}

Cólon biliar: um caso incomum de obstrução intestinal

\section{Dear Editor,}

A female, 80-year-old, diabetic, hypertensive and obese patient reported sudden onset of colicky pain in the hypogastrium for two days. Also, there was association with nausea, and the patient was unable to eliminate feces and pass gas, besides presenting with abdominal distension. Physical examination demonstrated increased abdominal volume, pain to deep palpation of the hypogastrium, abdominal tympanism to percussion and signs of mild dehydration. The clinical hypothesis of obstructive syndrome was raised.

Abdominal radiographic and sonographic images acquired in other service were not conclusive as regards the cause of the condition. Anteroposterior radiography in orthostasis and horizontal dorsal decubitus position demonstrated the presence of obstruc- tion with predominantly gaseous distension of small bowel loops and part of the large bowel, with no signs of pneumoperitoneum. Ultrasonography demonstrated gaseous distension with no signs of free fluid at the moment of the study. With such studies indicating low obstruction with no defined cause, one has opted for performing abdominal computed tomography (CT) in order to clarify the diagnosis and define the therapeutic approach.

Due to the clinical suspicion of neoplastic obstruction, the patient was referred to the authors' institution. With the CT study, the diagnosis could be established, and the several image reconstruction techniques - multiplanar, curve and $3 \mathrm{D}$ reconstruction - were utilized so as the findings could be presented to the requesting physician in a more easily understandable way.

CT demonstrated the fistulous tract communicating the gallbladder lumen with the lumen of the transverse colon and the presence of a residual calculus in the gallbladder (Figure 1A). Curve reconstruction of the rectal and sigmoid colon region demonstrated an impacted calculus obstructing the sigmoid colon and
Figure 1. A: Axial CT image demonstrating the presence of a calculus in the gallbladder (arrow) and fistulous tract communicating the gallbladder with the large bowel (asterisk). B: Curve reconstruction of CT image demonstrating impacted biliary calculus in the sigmoid colon (arrow) and bowel distension upstream (asterisk).
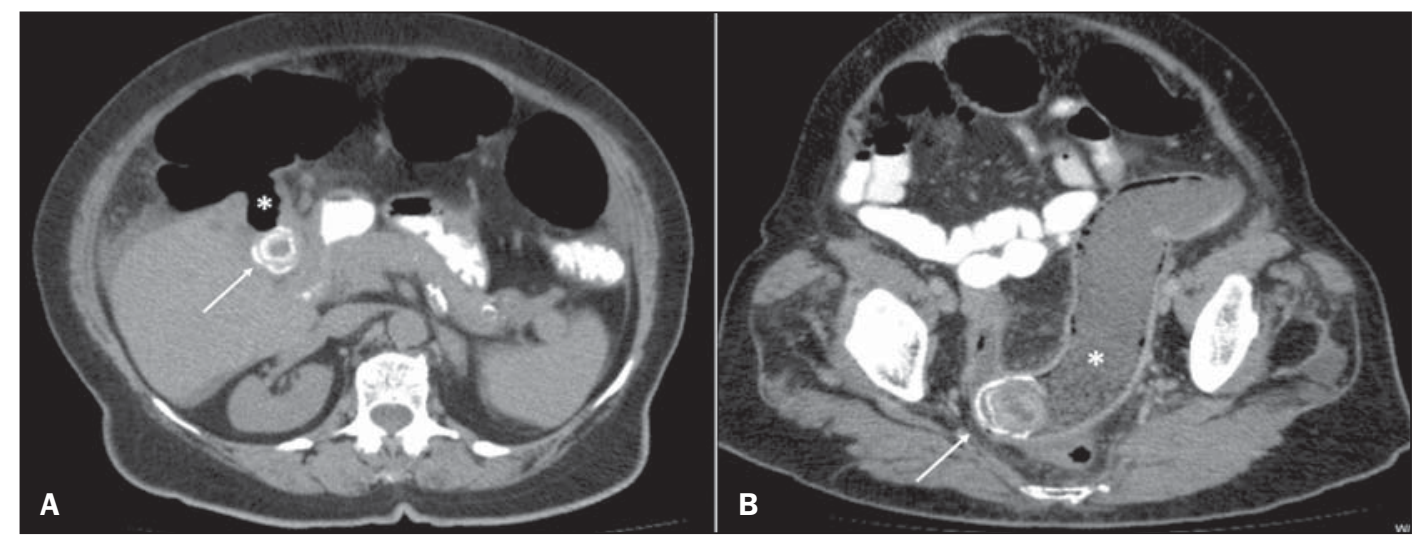


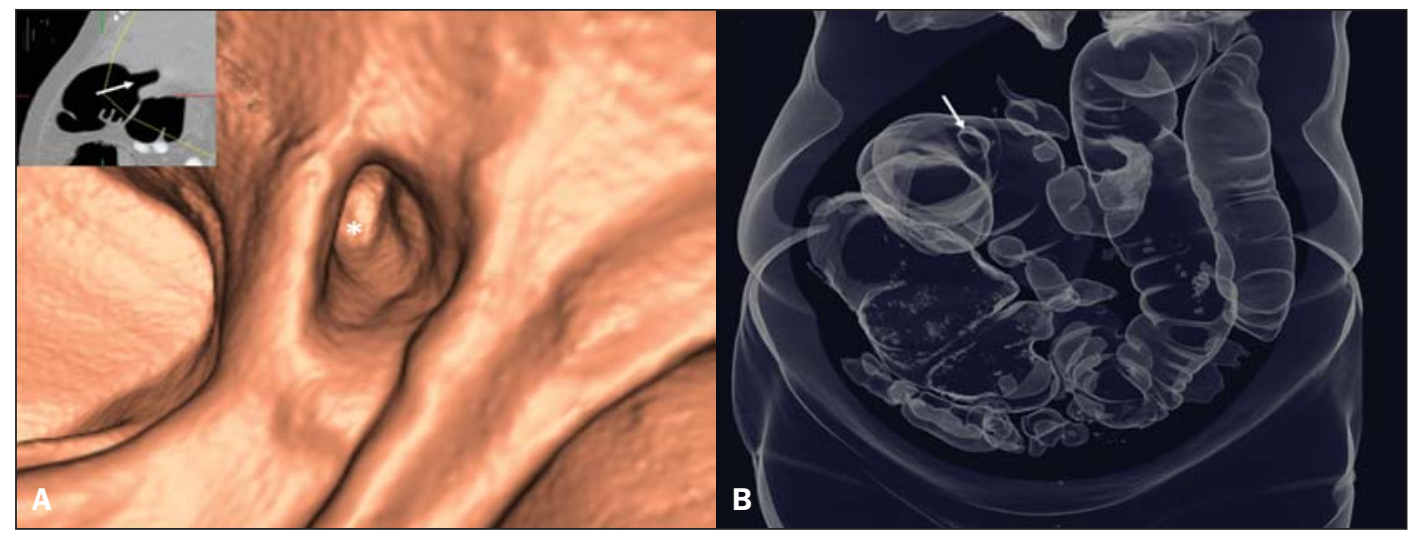

Figure 2. A: Endoluminal 3D reconstruction of virtual colonoscopy image demonstrating the fistulous orifice (asterisk) in the large bowel. The reference 2D image of the orifice positioning is highlighted (arrow). B: 3D reconstruction demonstrating gaseous bowel distention and the fistulous orifice (arrow). causing abdominal distension upstream due to fecal buildup (Figure 1B). Endoluminal reconstruction of virtual colonoscopy images demonstrated the fistulous orifice in the transverse colon (Figure 2A). Tridimensional reconstruction for gaseous material demonstrated diffuse gaseous distension of the right, transverse and left colons, and also the site of the choledochal-colonic fistula (Figure 2B). Once the diagnosis was established, the patient was successfully submitted to surgery.

Acute obstructive cholecystitis may approach the serosas of the biliary and intestinal tracts due to the gallbladder and/or common biliary duct dilatation. With the repetition of inflammatory episodes and adherence of the serosas, choledochal-colonic fistularization may occur, allowing for the passage of biliary calculi into the intestinal lumen ${ }^{(1)}$, besides calculi impaction at some point in the tract, causing significant pain, severe local irritation, edema or gangrene ${ }^{(2)}$. Amongst cholecystointestinal fistulas, cholecystoduodenal fistulas represent more than $70 \%$, while cholecystocolonic fistulas represent $8 \%$ to $26 \%$ of them ${ }^{(3)}$. Rigler et al. established four criteria (presence of air or contrast medium in the biliary tract; direct or indirect identification of calculus in the bowel; alteration in the position of a previously identified calculus; radiological signs of either partial or total occlusion of the intestinal lumen) which corroborate a diagnosis of bowel obstruction caused by a calculus ${ }^{(4)}$. Three findings determined by such criteria constitute the Rigler's triad: signs of small bowel dilation, pneumobilia and ectopic calculi.

Despite the rarity of this condition, one should be attentive to the possibility of biliary colon in acute onset of lower intestinal obstruction, in order to allow for a prompt and correct diagnosis and institution of an appropriate treatment.

\section{REFERENCES}

1. Wang JK, Foster SM, Wolff BG. Incidental gallstone. Perm J. 2009;13: $50-4$.

2. Costi R, Randone B, Violi V, et al. Cholecystocolonic fistula: facts and myths. A review of the 231 published cases. J Hepato Biliary Pancreat Surg. 2009;16:8-18.

3. Del Gaizo A, Raval B. Cholecystocolonic fistula. Applied Radiology. 2006; 35:21-2.

4. Smyth J, Dasari BV, Hannon R. Biliary-colonic fistula. Clin Gastroenterol Hepatol. 2011;9:A26.

Ernesto Lima Araujo Melo ${ }^{1}$, Francisco Thiago Martins de Paula $^{1}$, Rainne André Siqueiraa ${ }^{1}$, Sariane Coelho Ribeiro ${ }^{2}$

1. Universidade Estadual do Ceará (UECE), Fortaleza, CE, Brasil. 2. Hospital Israelita Albert Einstein, São Paulo, SP, Brazil. Mailing Address: Dr. Ernesto Lima Araujo Melo. Universidade Estadual do Ceará, Centro de Ciências da Saúde - Curso de Medicina. Avenida Paranjana, 1700 Campus do Itaperi. Fortaleza, CE, Brasil, 60740-000. E-mail: ernesto. melo@uece.br.

http://dx.doi.org/10.1590/0100-3984.2014.0073

\section{Catamenial pneumothorax}

Pneumotórax catamenial

\section{Dear Editor,}

A previously healthy 29-year-old woman presented at the emergency service complaining of sudden onset dyspnea. At physical examination the vesicular murmur was absent in the entire right hemithorax. Chest radiography demonstrated the presence of pneumothorax at right (Figure 1) and chest computed tomography $(\mathrm{CT})$ did not demonstrate any other alteration besides the already mentioned pneumothorax. Thoracotomy with underwater seal chest drainage was performed. As the pneumothorax presentation coincided with the patient's menstrual period, pelvic ultrasonography was performed and identified an image compatible with endometrioma in the left ovary. In three months, the patient evolved with a new spontaneous pneumothorax at right, and a pig-tail drainage tube was inserted. Later, thoracocoscopy was performed, and endometriotic foci were identified and resected (Figure 2). The chest wall was repaired with a Marlex mesh. After three months, the patient remains asymptomatic.

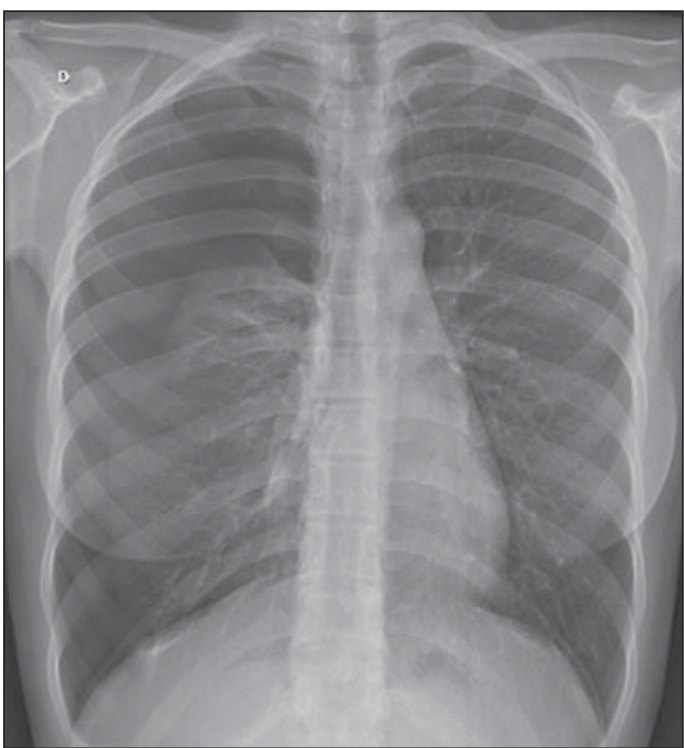

Figure 1. Chest radiography, posterior view showing pneumothorax at right. 